( Ю. С. Ганжуров, д-р політ. наук, проф., КП। ім. Ігоря Сікорського, Київ, Україна

\title{
КОМПОЗИЦІЯ КНИГИ У ВИДАВНИЧІЙ КОМУНІКАЦІї
}

\begin{abstract}
Розглядаються роль й місце композиції у видавничій комунікації, основні форми структуризаціії авторських оригіналів. Аналізуються особливості архітектоніки видання залежно від функціонального призначення та читацької адреси книги. Викладаються принципові засади організації фактичного матеріалу на рівні композиційної структуризації видавничих оригінал-макетів. Пропонується формула визначення інформаційної місткості тексту як основи оцінки релевантності контенту, його відповідності редакторським вимогам щодо якості фактичного матеріалу в частині його доцільності та повноти. Розкриваються фахова сутність композиції видання та її відмінності від композиції авторських оригіналів. Подано типологічні характеристики апарату книги як важливої складової композиції та видавничої комунікації.
\end{abstract}

Ключові слова: авторський оригінал; апарат книги; архітектоніка; видавничий макет; композиція; комунікація; план-проспект; редакторський аналіз тексту; рубрикатор.

\section{Постановка проблеми}

В умовах помітного посилення комунікативного потенціалу інформаційного суспільства українська книга, еволюціонуючи в різних формах її матеріалізації, стає реальним чинником соціальних трансформацій, інтелектуальних компетентностей й перспектив духовного розвитку нашої держави. Така тенденція пояснюється тим, що саме поняття «книга» перебуває у стані сталого розвитку, набуваючи все нових атрибутивних ознак, що випливають із сучасних моделей модернізації комунікативного суспільст- ва. Саме тому видається як актуальним, так й злободенним системне дослідження української книги як цілісного комунікативного механізму, продуманої системи залучення, організації та спрямування інформації за допомогою як традиційних прийомів створення контенту, так й шляхом залучення до комплексного комунікативного формування та композиційної структуризації сучасної методики роботи з текстом. Таким чином йдеться про аналітико-синтетичну критику книги як значної складової видавничої комунікації. В зв'язку із цим до- 
речно долучити до спорідненого аналізу класичні концепти сучасної комунікативістики, що можуть бути доволі ефективно адаптовані до архітектоніки видання. При цьому важливо взяти до уваги типологію видання, його функціональне призначення та читацьку адресу. Власне остання, реціпієнтна характеристика будьякої книги в частині пошуку комунікативного споживача, яким $€$ читач, свого часу заклала витоки формування власного формату видавничої комунікації. Саме цей сегмент став домінуючим при вивченні та ілюструванні наочними прикладами особливостей видавничої комунікації. Водночас інші складові цього процесу, передовсім сутність композиції видання, зокрема книги, її можливості формування контенту практично на всіх етапах комунікації мають бути актуалізовані в сучасному науково-дослідному процесі.

\section{Аналіз попередніх досліджень}

Питанням структурної організації інформації у виданні фахівці в галузі теорії й практики редагування приділяли належну увагу. Адже композиція книги залишається базовою категорією в оцінці якості підготовки видання до друку. В принципі видавничий оригінал-макет виступає репрезентантом композиції як результат редакторської роботи на всіх етапах підготовки рукопису до друку. Характерно, що фахівцями питання композиції розглядалися переважно у двох напрямах. Передовсім вивчалися загальні вимоги до структурної організації літературного матеріалу. В цьому плані хрестоматійними залишаються праці Р. Іванченка, А. Мільчина, В. Свінцова, М. Феллера, що присвячені класичній методиці побудови композиції на засадах позитивного досвіду, здорового глузду та формальної логіки. В подальшому їхні учні розвивали цю практику, збагачуючи теорію й практику редагування власними доробками, а головне - конкретизуючи загальнонаукові концепти й практичні рекомендації на рівні окремих видів літератури. Комунікативні особливості структуризації тексту наукових видань докладно вивчає Н. Зелінська. Про специфіку організації дитячої книжки професійно пише Е. Огар. Традиційно типізованою за архітектонікою викладу тексту вважається довідкова література. Ї̈̈ становлення та розвиток в Україні всебічно досліджує Н. Черниш. Доволі малодослідженою темою займається О. Тріщук, коли аналізує композиційну репрезентативність реферативної літератури. Заслуговує на увагу творчий доробок О. Янішевського в частині вивчення комунікативної організації та редагування документів. Вагомий внесок у створення наукової школи аналізу особливостей підготовки правової літератури зроблено М. Женченко. Таким чином сформувалася система знань про типологічні особливості композиції у видавничій комунікації. Характерно, що цей процес відбувався не лише в тематичному векторі, себто пошуку й класифікації особливих ознак, характерних для конкретного виду літератури. Мистецтво композиційної організації як важливий сегмент видавничої справи окреслює кілька важливих, відносно 
самостійних, проте пов'язаних спільним комунікативним задумом, сфер організації композиції, що вимагає спеціального дослідження.

\section{Мета роботи}

Видається актуальним виявити організаційні, структурні та інформативні особливості композиції на різних етапах формування видавничого оригінал-макета із врахуванням як традиційної методики структуризації контенту, так із залученням адаптованих до видавничих процесів форматів класичної моделі комунікації. Важливо вдосконалити систему комунікативних зв'язків між складовими композиції за рахунок підвищення інформативної компетентності учасників процесу створення видавничих оригіналмакетів: редакторів, репрографів, дизайнерів, графіків, а також менеджерів. Для цього має бути закладена основа для активізації міждисциплінарного навчального процесу у зазначеному напрямі.

\section{Результати проведених досліджень}

В останнє десятиліття теорія і практика редагування як прикладна наука та комплексна навчальна дисципліна, можливо, вперше за свою історію відчула такі серйозні виклики стрімкого розвитку комунікативних технологій, що виявили обмежені можливості фахівців-теоретиків галузі до адекватних проектів у частині вивчення, узагальнення, систематизації наявних практик. Такий стан справ В. Теремко пов'язує із «монодисциплінарним підходом, евристичним традиціо- налізмом, слабкою дослідницькою логікою, застарілим поняттєвим забезпеченням» [1, С. 5]. Безперечно, автор має рацію, якщо взяти до уваги той факт, що в нашій фаховій літературі довгий час під прапором професіоналізму в галузі панував історичний підхід, коли поступово, проте невпинно сегмент «теорія і практика редагування» підмінювався «теорією та історією» видавничої справи та редагування. Останнім часом ситуація поліпшується, але переважно за рахунок закордонного контенту, який збагачує передовсім галузеву навчальну літературу. У зв'язку з цим при аналізі, зокрема зображального потенціалу композиції видання, що його використовує дизайнер, важливо врахувати рівень фахової підготовки редактора-організатора майбутньої книги, який має забезпечити комунікативний зв'язок безпосередньо між текстом, його технічною модернізацією на шпальті складання, ілюстративним матеріалом й іншими візуальними елементами. Саме про гармонійне поєднання зазначених компонентів єдиної композиції пишуть спеціалісти 3. Сельменська та С. Комар: «Композиція друкованої продукції полягає у правильному впорядкуванні тексту з логічним поданням інформації та розміщенням ілюстративного матеріалу на полосі, тональній та кольоровій взаємодії елементів, а також здійсненні своєрідної маніпуляції поглядом читача» [2, С. 44]. Щоправда, тут впадає в око зазначена авторами «маніпуляція» як ознака того, що у них вочевидь $€$ когнітивна вада у визначенні 
причинно-наслідкових зв'язків послідовних процесів. Таким чином, як зазначалося, участь редактора у формуванні комплексної композиції майбутнього видання $€$ значною. На користь цієї думки слугуватимуть перевірені практикою методи формування ілюстративних планів. Їх сутність полягає у наступному: предметом ілюстрування $€$, по-перше, нові об'єкти; по-друге, об'єкти щодо яких не існує усталеної думки; по-третє, категорії, що подаються у порівняльному аналізі; по-четверте, об'єкти, які треба відтворити конструктивно. Звичайно, цим рекомендації щодо напрямів композиційного ілюстрування не обмежуються. Проте головним залишається правило: що ілюструвати визначає редактор-організатор, а яким чином художник-дизайнер книги [3]. Ілюстративно-текстова гармонізація композиції видання багато у чому залежить від попереднього погодження ії̈ концепції поміж авторами видавничого оригінал макета. У фаховій літературі цьому питанню не приділено належної уваги, можливо, саме через традиційну невизначеність компетенцій в управлінні цим процесом. Проте саме редактор має складати план ілюстрування авторського тексту, оскільки власне контент формує засади його візуалізації. Таким чином сюжет, вид ілюстрації, а також безпосередньо підпис як провідний комунікативний елемент визначаються в процесі комплексного редакторського опрацювання тексту.

Отже редакторський аналіз закладає основу композиції книги. Професійно структурований текст являє собою логічну систему комунікативних зв'язків внутрішньої організації: внутрітекстові рубрики, їх підпорядкування, різні види заголовків, інші засоби графічного відокремлення елементів тексту - все це дає підстави спеціалістам порушувати питання про особливості архітектоніки книги як типологічної характеристики композиції. У цьому плані А. Сидоренко трактує композицію, як «зовнішню формальну побудову твору, у якій формується своя внутрішня форма (архітектоніка)» [4, С. 21]. Аналіз відповідної літератури свідчить, що співвідношення зазначених понять, їхні атрибутивні відмінності ще не одержали усталеного виміру у фахових дослідженнях. Доречним видається підхід щодо неправомірності їхньої синонімії, хоча на практиці, в навчальному середовищі, це час від часу трапляється. Проте суттєвим принципом у розмежуванні цих понять буде еволюційний підхід, пов'язаний із неперервним процесом створення видавничого оригінал-макета. Можна погодитися із твердженням К. Серажим про те, що «композицію будь-якого тексту відображає його архітектоніка. Архітектоніка - це організація твору в плані вираження його змісту. Якщо поняття композиції стосується більше самого змісту тексту, то поняття архітектоніки - його форми, матеріалізації його змісту різними графічно-знаковими засобами» [2, С. 99]. У разі введення до кола викладених думок поняття «видання» співвідношення категорій «композиція» та «архітектоніка» набудуть дещо інших, проте, на нашу думку, цілком логічних 
позицій саме в системі видавничої комунікації. На нашу думку зрозуміло, що архітектоніку варто розглядати як похідну категорію щодо композиції. Водночас наочнішими її форми набуватимуться в тексті, якщо композицію ми будемо розглядати передовсім як структуру видання. Адже видання за змістом $є$ базовим поняттям, яке поглинає текст так само, як композиція є родовою рубрикою по відношенню до архітектоніки. Композиція видання, що з'ясовується під час дослідження нормативних документів, до певної міри визначається не лише видавничо-професійними традиціями, а й галузевими стандартами. Зокрема, ДСТУ «Видання. Основні види. Терміни та визначення» своїм класифікатором видань за цільовим призначенням по суті окреслює композицію наукової книги: «Видання, що містить результати теоретичних і (або) експериментальних досліджень, а також науково підготовлені до публікації пам'ятки культури та історичні документи з розгалуженим науково-довідковим апаратом (науково-дослідний, пояснювальний текст, коментарі, різноманітні покажчики)» [5, С. 9-10]. Проте, на жаль, автори стандарту виявилися непослідовними у дотриманні єдності класифікатора - у розділі «види неперіодичних видань за характером інформації» вони припустилися, на нашу думку, серйозної помилки, що в принципі унеможливлює класичну композицію монографії. Адже в стандарті монографія визначається як «наукове або науково-популярне видання» (!?). Поєднання в єдиному комунікативному форматі двох відмінних видавничих контентів фактично руйнує сам стандарт, робить його типологічно суперечливим, дезавуює функціональне призначення й читацьку адресу книги. Також чимало елементів, що ускладнюють структуризацію видання, містить стандарт по відношенню до довідкової, зокрема енциклопедичної літератури. В принципі видокремлення композиційних особливостей конкретного виду літератури, до певної міри позначене стандартом, виявляється доволі актуальним напрямом профільного дослідження. В цьому плані заслуговують на увагу класифікатори, що їх робить 3. Партико. Науковець визначає 9 видів композиції, а саме: оповідна, діалогова, вкладена, циклічна, описова, наукова, ієрархічна, архівна, гіпертекстова [6, С. 152-160]. Треба зазначити, що на даний час це чи не єдиний достатньо продуманий класифікатор композиції, що містить сучасна фахова література. Щоправда, дуже схожий за змістом перелік зазначених категорій свого часу подав давньоримський вчений і трибун Марк Фабій Квінтіліан. Саме він, можливо, вперше окреслив принципи, на яких ґрунтуються композиційні утворення, а саме: лінійна композиція - хронологічна послідовність викладу фактів; сходинкова - акцентує перехід від одного положення до іншого; концентрична - дає можливість перейти від одного положення до іншого з наступним поверненням до попереднього (за принципом спіралі); паралельна заснована на співставленні кількох фактів; дискретна - припускає пропуск окремих моментів 
викладу подій. Природно, що усталена практика композиційних структуризацій $€$ методичною основою для створення планпроспекту майбутнього видання. Ця відповідальна ланка видавничого процесу перебуває в центрі уваги спеціалістів [7, С. 13]. При цьому власне процес розробки та затвердження план-проспекту видання вважається саме «підготовчим етапом редакційновидавничого процесу» [8, С. 29]. Одначе практика доводить, що ключовою ланкою не підготовчого, а безпосередньо редакційного етапу $є$ робота автора та редактора над план-проспектом майбутнього видання. Адже від його якості залежить структура книги. Образно кажучи, проспект - це креслення будинку. Без першого не буде останнього в принципі. Тому вирішальним (а не підготовчим!) етапом редакторського процесу має вважатися створення план-проспекта як основи композиції книги. В теорії видавничої справи циркулює судження про план-проспект як певний перелік розділів і підрозділів майбутнього видання. Інколи зазначають, що цей перелік має бути анотованим. На нашу думку, доцільно визначити план-проспект як детальний перелік усіх видів рубрик майбутнього видання, у їхній родо-видовій підпорядкованості. Важливо наголосити саме на максимальному представництві у плані всіх одиниць рубрикаційного поділу: від інформаційних заголовків першого рівня до елементарних, якими можуть виступати навіть абзаци в тексті (номінувати їх треба ключовими словами - «символами-інформантами»). Отже, в першу чергу рівень конкретизації змісту план-проспекту відрізняється від звичного для читача робочого змісту (оглав) книги, який, до речі, є частиною композиції видання. При визначенні факторів ефективності комунікативної складової план-проспектів видається важливим забезпечити дотримання єдиної основи поділу понять при побудові родо-видової класифікації рубрик. На жаль, цієї вимоги частогусто не дотримуються ні автори, ні редактори. В результаті утворюється хаотична композиція, що суперечить логічним нормам викладу матеріалу. Це по-перше. По-друге, важливо враховувати, що в план-проспекті майбутнього видання сума видових рубрик має дорівнювати змістові родової рубрики. У разі дотримання цього правила забезпечуватиметься повнота викладу фактичного матеріалу рукопису. 3 повнотою фактичного матеріалу безпосередньо пов'язана проблема його пропорційного викладу на рівні композиції. Себто, по-третє, кількісне представництво видових рубрикаторів у кожному родовому рубрикаторі має бути пропорційним одне одному. Нарешті, по-четверте, сама послідовність рубрикаційного поділу не може бути випадковою. В даному разі йдеться про обов'язкову обґрунтованість такого переліку. Він може бути технологічним, хронологічним, дедуктивним, індуктивним, зрештою, побудованим за абетковим принципом. Головне: він завжди має бути обґрунтованим. Природно, що планпроспект відрізняється від робочого змісту (оглаву) рукопису не лише за обсягом. Він може бути суттєво відмінним від останнього 
за назвами рубрикатора композиції. В цьому полягає комунікативна сутність план-проспекта.

В принципі сам процес трансформації план-проспектів в композицію авторських оригіналмакетів доцільно розглядати через еволюцію назв заголовків. Ці рубрикатори змінюються відповідно до наявності текстів, які вони представляють. План-проспекти текстів ще не мають, максимум - розлогі анотації. Отже за таких умов заголовок має бути максимально інформативним на відміну від повноцінного рукопису, де той самий розділ, що в план-проспекті, може мати інший, навіть «сліпий» заголовок, що б примушував реципієнта прочитати текст. Але для вивчення комунікативних потенціалів авторських оригіналів нас передовсім цікавить інформаційна місткість рукопису. Ї̈̈ нам дає рубрикаційний поділ, точніше його одиниці, як ми вже згадували, символи-інформанти. Вони $€$ безпосередніми репрезентантами релевантної інформації, що міститься в рукописі. У зв'язку із цим заслуговують на увагу пропозиції, що їх роблять С. Знахур іО. Мізяк. Дослідники пропонують різні моделі пошуку релевантної інформації у відповідних електронних ресурсах [9, С. 20-23].

Для цього нами розроблена формула виявлення релевантної інформації в авторських оригіналах, а саме:

$$
\text { I. i. } \mathrm{H}=\frac{\Phi_{\mathrm{o}}}{\mathrm{K}_{\mathrm{c}-\mathrm{i}}}
$$

де І.і.н - індекс інформаційної насиченості оригіналу; $\Phi_{о}-\phi і-$ зичний обсяг рукопису в знаках; $\mathrm{K}_{\mathrm{C}-\mathrm{i}}$ - кількість символів-інформантів в рукописі.

Для даного дослідження з'ясування рівня інформаційної насиченості рукопису важливе тому, що конкретизація змісту на рівні символів-інформантів $€$ внутрішнім рубрикатором як архітектоніки основного тексту, так й композиції видання в цілому. Відомо, що репрезентантом завершеної композиції книги є остаточний видавничий оригінал-макет, невід'ємною частиною якого виступає апарат видання. Цьому розгалуженому механізму управління комунікацією книги приділяється чимало уваги з боку дослідників. Як зазначає знаний фахівець редакторської справи А. Мільчін «успіх книги та створеного редактором чи під його керівництвом апарату, що найбільш відповідає інтересам читача, міститься у вільній творчій думці редактора, в його майстерності функціонального аналізу, котре не може не призвести до створення нових видів й форм апарату...» [10, С. 235]. У цьому контексті доречно згадати про класифікатор за авторством М. Тимошика він називає «апарат видання» поняттям «службова частина» [11, С. 235]. Не вдаючись до характеру можливої дискусії на цю тему, зауважимо, що в даному разі доцільність застосування зазначеного класифікатора дозволяє розмежувати те, що М. Тимошик називає змістовною, себто основною частиною видання, від власне апаратної складової композиції книги. В принципі, як відомо, про терміни не сперечаються, про терміни домовляються. Це загальновідома 
істина. В даному разі просто доцільно зосередитись не на формі, а змістові, проаналізувавши усі сутнісні категорії поняття «апарат книги». При цьому ми виходитимо із думки Н. Блоговірної про можливості апарату книги забезпечити «можливість переходу від інтуїтивно читацького до осмисленого розуміння авторського тексту [12, С. 154]. Для ґрунтовного розуміння основної комунікативної мети апарату книги як вагомої частини композиції видання доцільно розглянути його основні функції. Перша - контактно-інформаційна. Передовсім вона представлена назвою твору та відомостями про автора. Саме тут на перше місце висувається дизайн контактної інформації: технічна редакція текстів, композиція шпальти складання тощо. Проте основним елементом контактно-інформаційної функції $€$, звичайно, назва твору. Фахівці приділяють чимало уваги питанням якості назви (заголовку) тексту. При цьому висувають чимало вимог. На нашу думку, головна з них - відповідність назви змісту книги. Досвід видавничої практики вчить: до цієї вимоги треба підходити враховуючи вид літератури, її функціональне призначення та читацьку адресу. Звичайно, використання метафоричних та іншого виду інтригуючих заголовків, що буквально не відбивають зміст книги, можна пояснити маркетинговими мотиваціями. Проте значний масив літератури, передовсім наукової та навчальної, вимагає конкретних назв, а в окремих випадках ще й конкретизацію заголовків. Здійснюється вона за допомогою підзаголов- кових даних. До речі, це явище безпосередньо пов'язане із проблемою повноти фактичного матеріалу рукопису. Друга функція апарату - орієнтовно-довідкова. Вона полягає у розкритті комунікативних можливостей таких елементів, як передмова, анотація, зміст чи оглав книги. Незважаючи на доволі представницький характер передмови як за авторським складом, так й за способом подачі інформації, цей вид тексту залишається малодослідженим контентом комунікації із точки зору його композиційної взаємодії із основним текстом рукопису. Частогусто передмови, особливо до академічних видань, стають настільки органічно-самостійними, незалежними від базового контенту творами, що наданий таким текстам окремо знак охорони авторського права видається абсолютно логічним. Також актуальним залишається дослідження процесів створення анотації. Це пов'язано з тим, що останнім часом професійні вимоги до підготовки анотації знижені. Передовсім це стосується визначення читацької адреси видання. Вона на даний час $€$ настільки уніфікованою, що віднайти в анотації потенційного споживача інформації проблематично. Проте усвідомлення комунікативної важливості анотації як допоміжної складової композиції видання спостерігається на рівні спеціальних публікацій. Зокрема, Ю. Полтавець влучно помічає, що «неякісна анотація може бути причиною комунікативної невдачі» [13, С. 5]. Саме тут важливо звернути увагу на авторське спостереження поширеної 
вади, яку влучно діагностували як комунікативна невдача. Отже, йдеться про роль анотації у видавничій комунікації. Для того, щоб визначити її роль й місце в зазначеному процесі, треба звернутися до відомої комунікативної моделі Г. Лассуелла, що передбачає відповіді на наступні питання: хто повідомляє про що - в який спосіб - з якою метою - $з$ яким ефектом. Адаптація зазначених вимог для специфіки видавничої практики дозволяє зробити висновок, що прикнижкова анотація $є$ синтетичним комунікативним жанром. ї̈̈ належна професійна підготовка може забезпечити реалізацію зазначеної моделі у конкретному випадку підготовки книжкового видання та його наступного поширення в інформаційному середовищі. Проте якщо анотація $€$ обов'язковим елементом апарату (службової частини) видання, то покажчики характерні для окремих видів літератури. На наш погляд, дослідникам варто зосередитись на виявленні типологічних залежностей покажчиків від виду літератури, оскільки в класичному варіанті аналізувати структури покажчиків, логіку їх створення, зрештою - сам зміст без врахування особливостей тексту непродуктивно. Це набуває актуальності в наш час, коли фахівці наголошують на ролі покажчиків у формуванні тематично-проблемних баз даних [14, С. 211]. В наш час розвитку електронних видань комунікативні функції покажчиків, перспективи їх варіативності й мобільності важко переоцінити й навіть докладно спрогнозувати.

\section{Висновки}

Таким чином, розглядаючи композицію книги в системі видавничої комунікації, можна визначити їі специфіку у трьох основних аспектах. По-перше, йдеться про книгу як внутрішню систему організації контенту за законами та правилами логічного викладу інформації, що в свою чергу обумовлює сутність архітектоніки головного тексту. По-друге, усвідомлюється роль композиції видання, що відмінна від композиції рукопису через оцінку комунікативних можливостей апарату видання, оскільки його складові виконують контактноденонативні функції поширення інформації. По-третє, важливо наголосити, що книга, після їі виходу в світ, стає тим учасником видавничої комунікації, який впливає на систему суспільних цінностей, а сам формує моделі соціальної поведінки, збагачує контентом лідерів думок тощо. Отже книга виступає як суб'єктом, так й об'єктом видавничої комунікації, оскільки її композиція є результатом гармонійної аналітико-синтетичної праці усіх учасників комунікативного процесу, але передовсім - редактора як організатора видання книги. Для підвищення ефективності навчального процесу, що передбачає комплексну підготовку всіх професій видавничо-поліграфічної галузі, вбачається доречним надати питанням оптимізації міждисциплінарних напрямів саме змістовну орієнтацію на всебічне вивчення композиції видання як провідної теми в підготовці фахівців галузі. 


\section{Список використаної літератури}

1. Теремко В. І. Видавництво - XXI. Виклики і стратегії: монографія / В. І. Теремко. Київ: Академвидав, 2012. 328 с.

2. Серажим К. Композиція та архітектоніка тексту: принципи редакторського втручання / К. Серажим // Масова комунікація: Історія, сьогодення, перспективи. 2014. № 5-6. С. 95-99.

3. Іванов С. І. Основи композиції видання: навч. посіб. / С. І. Іванов. Львів: Світ, 2013. 229 с.

4. Сидоренко А. І. Архітектоніка та композиція художнього твору як елементи авторського ідіостилю / А. І. Сидоренко // Вісник університету імені Альфреда Нобеля. 2019. № 1(17). С. 19-24.

5. ДСТУ 3017: 2015. Видання. Основні види. Терміни та визначення понять. Київ: ДП «УкрНДЦ», 2016. 36 с.

6. Партико 3. В. Загальне редагування: нормативні основи: навч. посіб. / 3. В. Партико. Львів: Афіша, 2001. 416 с.

7. Методичні рекомендації для підготовки рукописів навчальної та наукової літератури, видання у видавничо-поліграфічному центрі та розміщення в інституційному депозиторії Університету державної фіскальної служби України / [уклад. Л. Л. Таранчук, О. О. Бойко-Слобожак, С. В. Новицький, Д. Ф. Салахова, С. Я. Цимбалюк; за ред. П. В. Пашка]; Університет державної фіскальної служби України. Ірпінь, 2017. 24 с.

8. Кудряшова А. В. Інформаційна технологія прогностичного оцінювання якості редакційно-видавничого процесу випуску книжкових видань. Кваліфікаційна наукова праця на правах рукопису / Дисерт. на здобуття наук. ступеня канд. тех. наук. (за спец. 05.13.06. - інформ. технології) / А. В. Кудряшова. Львів: Українська академія друкарства, 2018. 197 с.

9. Знахур С. В. Алгоритми пошуку релевантних документів у інформаційних мережах / С. В. Знахур, О. Ю. Мізяк // Системи обробки інформації. 2012. Вип. 8(100). С. 20-23.

10. Мильчин А. Э. Подготовка и редактирование аппарата книги: Как сделать книгу удобной для читателя / А. Э. Мильчин. М.: Шк. изд. и медиа бизнеса: Унив. кн., 2011. 256 с.

11. Тимошик М. С. Як редагувати книжкові та газетно-журнальні видання: Практичний посібник / М. С. Тимошик. К.: Наша культура і наука, 2012. 384 с.

12. Благовірна Н. Б. Апарат видання як інтелектуальна автономність читача / Н. Б. Благовірна // Поліграфія і видавнича справа. 2017. № 2(74). C. $147-162$.

13. Полтавець Ю. Анотація як засіб комунікації між видавництвом і читачем / Ю. Полтавець // Вісник книжкової палати. 2017. № 2. С. 3-5.

14. Опря Т. М. Покажчик як форма розповсюдження бібліографічної інформації / Т. М. Опря // Наукові праці Кам'янець-Подільського національного університету ім. І. Огієнка. Кам'янець-подільський: Кам'янецьподільський нац. ун-тет ім. І. Огієнка, 2013. С. 211-216.

15. Сельменська 3. М. Теоретичні аспекти побудови якісної композиції в поліграфії / 3. М. Сельменська, С. М. Комар // Поліграфія і видавнича справа. 2017. № 12(74). С. 43-50.

\section{References}

1. Teremko, V. I. (2012). Vydavnytstvo - XXI. Vyklyky i stratehii: monohrafiia [Publishing House - XXI. Challenges and Strategies]. Kyiv: Akademvydav, 328 p. [in Ukrainian]. 
2. Serazhym, K. (2014). Kompozytsiia ta arkhitektonika tekstu: pryntsypy redaktorskoho vtruchannia [Composition and Architectonics of the Text: Principles of Editorial Intervention]. Journal of Masova komunikatsiia: Istoriia, sohodennia, perspektyvy, 5-6, 95-99 [in Ukrainian].

3. Ivanov, S. I. (2013). Osnovy kompozytsii vydannia [Fundamentals of Composition of the Edition]. Lviv: Svit, 229 p. [in Ukrainian].

4. Sydorenko, A. I. (2019). Arkhitektonika ta kompozytsiia khudozhnoho tvoru yak elementy avtorskoho idiostyliu [Architectonics and Composition of a Work of Art as Elements of the Author's Idio-Style]. Journal of Visnyk universytetu imeni Alfreda Nobelia, 1(17), 19-24 [in Ukrainian].

5. (2016). Vydannia. Osnovni vydy. Terminy ta vyznachennia poniat: DSTU 3017: 2015. [Edition. The Main Types. Terms and Definitions]. Kyiv: DP 'UkrNDTs', 36 p. [in Ukrainian].

6. Partyko, Z. V. (2001). Zahalne redahuvannia: normatyvni osnovy [General Editing: Normative Bases]. Lviv: Afisha, 416 p. [in Ukrainian].

7. (2017). Metodychni rekomendatsii dlia pidhotovky rukopysiv navchalnoi ta naukovoi literatury, vydannia u vydavnycho-polihrafichnomu tsentri ta rozmishchennia $v$ instytutsiinomu depozytorii. Universytetu derzhavnoi fiskalnoi sluzhby Ukrainy [Methodical Recommendations for the Preparation of Manuscripts of Educational and Scientific Literature, Publication in the Publishing and Printing Center and Placement in the Institutional Depository of University of the State Fiscal Service of Ukraine]. Irpin: Universytet derzhavnoi fiskalnoi sluzhby Ukrainy, 24 p. [in Ukrainian].

8. Kudriashova, A. V. (2018). Informatsiina tekhnolohiia prohnostychnoho otsiniuvannia yakosti redaktsiino-vydavnychoho protsesu vypusku knyzhkovykh vydan [Information Technology of Prognostic Assessment of Quality of EditorialPublishing Process of Issue of Book Editions]. Lviv: Ukrainska akademiia drukarstva, 197 p. [in Ukrainian].

9. Znakhur, S. V. \& Miziak, O. Yu. (2012). Alhorytmy poshuku relevantnykh dokumentiv $\mathrm{u}$ informatsiinykh merezhakh [Algorithms for Searching Relevant Documents in Information Networks]. Journal of Systemy obrobky informatsii, 8(100), 20-23 [in Ukrainian].

10. Mil'chin, A. E. (2011). Podgotovka i redaktirovanie apparata knigi: Kak sdelat' knigu udobnoy dlya chitatelya [Preparation and Editing of the Book Apparatus: How to Make a Book Convenient for the Reader]. Moscow: Shk. izd. i media biznesa: Univ. kn., 256 p. [in Russian].

11. Tymoshyk, M. S. (2012). Yak redahuvaty knyzhkovi ta hazetno-zhurnalni vydannia [How to Edit Book and Newspaper-Magazine Editions]. Kyiv: Nasha kultura i nauka, $384 \mathrm{p}$. [in Ukrainian].

12. Blahovirna, N. B. (2017). Aparat vydannia yak intelektualna avtonomnist chytacha [Apparatus of Publication as an Intellectual Autonomy of the Reader]. Journal of Polihrafiia i vydavnycha sprava, 2(74), 147-162 [in Ukrainian].

13. Poltavets, Yu. (2017). Anotatsiia yak zasib komunikatsii mizh vydavnytstvom i chytachem [Annotation as a Means of Communication between Publishing House and Reader]. Journal of Visnyk knyzhkovoi palaty, 2, 3-5 [in Ukrainian].

14. Opria, T. M. (2013). Pokazhchyk yak forma rozpovsiudzhennia bibliohrafichnoi informatsii [Index as a Form of Distribution of Bibliographic Information]. Journal of Naukovi pratsi Kam'ianets-Podilskoho natsionalnoho universytetu im. I. Ohiienka. Kam'ianets-podilskyi: Kam'ianets-podilskyi nats. un-tet im. I. Ohiienka, 211-216 [in Ukrainian]. 
15. Selmenska, Z. M. \& Komar, S. M. (2017). Teoretychni aspekty pobudovy yakisnoi kompozytsii v polihrafii [Theoretical Aspects of Construction of Qualitative Composition in Polygraphy]. Journal of Polihrafiia $i$ vydavnycha sprava, 12(74), 43-50 [in Ukrainian].

The role and place of composition in publishing communication, the main forms of structuring of author's originals are considered. Features of the publication's architectonics depending on the functional purpose and the reader's address of the book are analyzed. The basic principles of organization of factual material at the level of compositional structuring of publishing original layouts are stated. The formula of definition of information capacity of the text as a basis for estimation of content's relevance, its conformity to editorial requirements concerning quality of actual material in a part of its expediency and completeness is offered. The professional essence of the composition of the publication and its differences from the composition of the author's originals are revealed. The typological characteristics of the book apparatus as an important component of composition and publishing communication are given.

Keywords: author's original; book apparatus; architectonics; publishing layout; composition; communication; prospectus plan; editorial analysis of the text; rubricator.

Рецензент - М. Т. Андрійчук, канд. наук із соц. комунікацій, доц., КП ім. Ігоря Сікорського 